\title{
DISHING UP ISRAEL: RETHINKING THE POTENTIAL OF LEGAL MIXITÉ
}

\section{Susan G. Drummond*}

The field of mixed legal studies has recently been engaged in discussions about the virtues of merit-driven versus integritydriven judgments in law making. Integrity-driven judgements aspire to locate solutions in a way that will generate greater coincidence with one overall legal tradition in settings where two or more are mixed. The latter style of judgement has historically preoccupied mixed jurisdictions where the Civil law has felt the need to struggle for its place when paired with a dominating Common law alter. A more pragmatic merit-driven approach has been advocated for by some mixed jurisdiction scholars as a means of allowing the mixite to flourish according to its contemporary context and bundle of sociological needs. This paper reexamines the tension between these two approaches to judgement. It does so by taking a slightly off-kilter look at mixité in one of the more vexed and volatile mixed jurisdictions in the world: Israel/Palestine. The paper does not take as a point of inquiry either the classic Civil law/Common law mix of the jurisdiction, nor its increasingly more strident religious law/secular law tension. The paper, rather, focuses and elaborates upon one of the reigning metaphors of mixed legal studies - food - through the most prominent tension of the jurisdiction - Israeli/Palestinian - and pushes that metaphor in ways that might better reflect the dialogic and contested nature of all mixités.

Dans le domaine d'étude de systèmes juridiques mixtes, on a récemment engagé des discussions au sujet des vertus de jugements axés sur le mérite par opposition à ceux axés sur l'identité dans le développement de la loi. Les jugements axés sur l'identité visent à trouver des solutions d'une façon qui créera une plus grande correspondance avec une tradition juridique dans son ensemble dans les contextes où il en existe deux ou plus. Historiquement, ce dernier style de jugement a préoccupé les juridictions mixtes où le droit civil a senti le besoin de lutter pour conserver sa place lorsquil coexiste avec l'alternative du droit commun dominant. Une approche plus pragmatique axée sur le mérite a été préconisée par certains spécialistes de juridictions mixtes dans le but de permettre à la mixité de prendre de l'essor en fonction de son contexte contemporain et d'un ensemble de besoins sociologiques. Cet article réexamine la tension entre ces deux approches au jugement. Il le fait en jetant un regard un peu insolite sur

* Professor of Law, Osgoode Hall Law School 
la mixité dans une des juridictions mixtes les plus problématiques et les plus explosives au monde: Israël/Palestine. Larticle ne prend comme sujet d'analyse ni la combinaison classique droit civilldroit commun de la juridiction, ni sa tension de plus en plus stridente droit religieux/droit séculier. Plutôt, il porte sur et élabore une des métaphores dominantes des études de systèmes juridiques mixtes - la nourriture - à travers la tension la plus prononcée de la juridiction - israélien/palestinien - et développe cette métaphore de façons qui pourraient mieux refléter la nature dialogique et contestée de toutes les mixités.

\section{PERMLXTIO JURIDICA}

Like many travelers, when I return to Jerusalem, I start out by walking through the anfractuous streets of the Old City, past the vendors selling fresh-squeezed orange or pomegranate juice alongside falafel with chips, losing myself in the smells of wood smoke and zaatar, ${ }^{1}$ incense and mint, fresh ripe produce crushed underfoot, and diesel oil. And now I also always find my way to the table at the back of Ghassan's shop where necklaces and earrings are strung together under a poster, now ubiquitous in the homes and shops of Palestinians, of the new "separation"/"apartheid" wall's path.

In a cubby hole no more than three feet by four feet, at the end of an alley across the way, Kareem, feeding his children by doing the work that his father used to do, pulls steaming hot mint tea from the copper boiler he's been paying off for five years, spoons sugar from a metal dish in the sink into several glasses, clips fresh mint bought from one of the women who squat against the wall next to their heaps of the herb, places the glasses on a circular silver tray and, grasping the handle that arches over the tray with the confidence of someone who daily maneuvers glasses of tea through the crush of endless crowds of tourists, swings out to the shops that have called upon his services for the ritual hospitality.

Kareem, and his father before him, had been serving mint tea at the beck and call of the Old City merchants. The Israeli tax authorities descended upon his cubby hole one day and informed him that he owed back taxes amounting to the cost of his copper boiler. Kareem told them they could shut him down and seize his meager equipment; they would never see a shekel in taxes from him.

Sometimes, in addition to the tea, Ghassan sends his son Nabil out to get pizza for us, or plates of Knafeh Nabulsieh (baked cheese topped with crumbled orange sweetness). Sometimes Ghassan's wife, Amira, has sent Nabil into Ghassan's shop in the Arab Shuk with a hot dish of stuffed cabbage rolls, lemon quarters, pita, and, as it is contentiously described in falafel restaurants in Toronto, "Israeli" salad - finely chopped cucumbers, scallions, and tomatoes drizzled with lemon juice and extra-virgin olive oil.

Ghassan cannot - he smiles simultaneously proud and self-deprecating stop doing business. Even with his friends. He winkingly chastises himself as he catches himself mid-sentence saying "for you, because you are a friend, I will sell

1 Zaatar usually consists of some combination of wild oregano, thyme, sumac and sesame seeds. 
them to you for...." We are sitting at the table at the back of his shop, drinking Kareem's mint tea. Ghassan is speaking to Sara, an extravagantly bejeweled Iraqi Jew who has come from Tel Aviv with her daughter Elinor to renew her old habit of selling wholesale jewelry to Ghassan after years of staying away from the unspoken terrors of the Arab quarter. ${ }^{2}$ They speak together in Hebrew, switching to English when I arrive. Sara jokes that Ghassan thinks in Arabic, talks in English, and trades in shekels. He has already agreed to buy multiple samples of the jewelry that she has spread out in small, plastic, Ziploc bags, having weighed them on his digital scale and closed on a price.

Sara's eye has been caught by the delicate glass vials inside glass cases that Ghassan brought back from Egypt. She has also been querying him about the brown and amber oils in the cut glass jars on the far shelf. She can't buy these in Tel Aviv, she says. How much? And, after handling each with a care that reinforces the delicacy of the blown and spun glass, after pouring out small samples of jasmine and musk and lavender for us to smell, he catches himself with his disarming description of what has been just started going on again, in the old city, between whole sellers and retailers, tea sellers and tourists.

In the back of Ghassan's shop, on separate occasions, I have met three of the Sephardic jewelry wholesalers who have started to return to the Arab quarter to do business. One of them, an Iranian Jew, is called Schmuel. After Ghassan had ended a sour engagement seventeen years ago, Schmuel told Ghassan that he had found the perfect woman for him in Bethlehem - Amira, the maker of the cabbage roles and the mother of Ghassan's four beloved children.

Ghassan cannot stop doing business, and he's brilliant at it, a Jewish tour guide tells me as we huddle briefly in the rain outside his shop one day. She had taken a group to eat at the best place in Israel to get hummus, she said. It's just four shops down from Ghassan's. On the day that she was leading the group, the line-ups were off-putting. Ghassan noticed the dismayed crowd and insisted that they come in while he ordered dishes of the hummus and pita to be delivered directly to the table at the back of his shop. Several hours later, the group left sated, after also spending hundreds and hundreds of dollars on Ghassan's jewelry.

Hummus and pita. And falafel. I have heard many Israeli Jews lament the loss of the days that they used to eat hummous and falafel with their Arab friends in the Old City, as though sharing the food alone created a bond, made them compatriots, meant that they were sharing the same space, were convivial and hakol b'seder (copacetic), with each other.

\section{INTRODUCTION}

Hummus and Falafel. "Israeli" salad. Israeli/Palestinian food. A palatable entrée for a discussion on the mixed legal jurisdiction of Israel.

Somewhat strikingly, associations between food and law predominate in the

2 In February of 2005, an informal truce took tenuous hold between Israel and both Fatah and Hamas after the violence of the second intifada saw not only a huge downward turn in tourism in Israel/Palestine, but also a significant reduction of interaction between Palestinians and Jews, Eastern Jerusalemites and Western Jerusalmites, in particular in the Arab quarter of the Old City. This truce brought tourists back to the Old City. 
literature on mixed legal jurisdictions, making an elaboration upon them a seemingly irresistible point of entry. This article seeks to expand our understanding of mixed legal jurisdictions using Israel/Palestine's legal mixité as its locus of inquiry - and deploying food as its reigning metaphor.

The focus on Israel/Palestine as a prototypical mixed legal jurisdiction - and the use I intend to make of food as a metaphor to understand both Israel's mixité and to get at a more dialogic understanding of mixed legal traditions - require some initial explanation.

Israel proper is a classic mixed legal jurisdiction; that is, in its private law, Israel has historical and contemporary elements of both Common law and Civil law, the first deriving from the British Mandate, the second from civilian elements in the antecedent Ottoman-Turkish Empire and from the importation of Civilian lawyers and legal academics immediately after the Holocaust as the new state was forming. The nature of this classic mix has been written about elsewhere ${ }^{3}$ and it is not the intention of this paper to explore in depth the relation between each of these two major legal traditions within Israel's body of private law.

Israel has another, much less noted, though equally (if not more) intriguing mix in the domain of family law, in which a dizzying array of religious bodies of law and institutions compete, in asymmetrical ways, with the secular law of the state. Israel does not recognize secular marriage or divorce and recognizes multiple religious jurisdictions over both marriage formation and dissolution. Substantive areas of family law such as alimony and custody are addressed in parallel, and often competing, religious and secular courts, according to parallel and often competing bodies of law. This mix is increasingly being written about in a way that challenges the hegemony of the Civil law/Common law binary as the core tension in mixed legal jurisdictions. Intriguing as this new direction in mixed legal studies is, it is not the intention of this paper to explore in depth the ways in which religious and secular law interact within Israeli/Palestinian law and society.

Rather than explore Israel/Palestine's classic Common law/Civil law mix, or its more dizzying family law mix, this paper is devoted to exploring a way to approach mixed legal studies, through its reigning metaphor - food - and against a far more vexed and volatile mix: that of Israelis and Palestinians. Although the opening segment begins in Jerusalem, because this larger, and less jurisdictionally settled, opposition figures more prominently in the paper, the relevance of whether the article is bound to that unsettled city, or the mix of law within the pre-1967 borders, or the mixed law of the occupied territories recedes.

The real tension at the heart of this article is between the virtues of meritdriven uses and integrity-driven uses of legal mixité - both taking place against the background of a mundane, taken-for-granted world punctuated in surprising ways by salience. In an attempt to get at a more dialogic, contextual way of conceiving of mixed jurisdictions, the paper aims to look at the back and forth between identity politics in mixed jurisdictions and the pragmatics of how to

3 See Celia Wasserstein Fassberg, "Language and Style in a Mixed System" (2003) 78 Tul. L. Rev. 151; Stephen Goldstein, "Israel” in Vernon Valentine Palmer, ed., Mixed Jurisdictions Worldwide: The Third Legal Family (Cambridge: Cambridge University Press, 2001). 
get along; to look at the undercurrents running underneath nationalist law and pragmatic, merit-driven law - through how such tensions are iterated through the ideology of food. The paper does not aspire to look directly at the articulation of integrity and merit-driven arguments in law, but rather to look at how law's analogue in nationalist politics - food - recedes into the everyday and erupts at surprising moments as a fulcrum of discontent. What would be commonplace exchanges and transactions in a pacific setting - an understanding of offer and acceptance in contract law, a falafel with hummus - carry a freight of perils, often painstakingly itemized in a manner that perhaps only a lawyer would find intuitive.

The utility of Israel/Palestine for this focus upon the mundane and the salient arises from the intuition that the taxonomic approach to both comparative law and mixed legal studies is so ill-equipped to describe the dynamics of encounter in that region. A focus upon Israel's complex and often anguished political mix makes it very difficult to ignore the tension-filled and warring dimensions not infrequently characteristic of socio-legal mixing - exactly where mixed legal studies would prefer us to focus on settled mixed jurisdictions, on places where jurisdiction and territory are no longer so openly in dispute. The rawness of Israel's most prominent bellum juridicum - not the tamed Civil law/Common law one, nor the unwieldy yet tensely cohabiting religious/secular one, but the Israeli/Palestinian one - allows us to revisit the historical moments in most mixed jurisdictions when bellum gave surviving mixed jurisdictions their leading characteristic. Focusing on mixed jurisdictions such as Israel/Palestine, perhaps most particularly when relationships are frayed, provides an opportunity to look more closely at the processes that create the distinctive legal self, as well as those legal selves that are more indiscriminate and promiscuous, or thrown into confusion, or subservient.

The first (and vaguely ethnographic) part of the paper - Permixtio Juridica - is above. It lays out a prosaic scene that is rife with any number of elements that could be explored for their bellicose potential, from the tax authorities, to the tense assertions of authority over the city, to the renewals and manipulations of commerce and a single economic sphere, to the internal dynamics between Sephardic and Ashkenazi Jews and their relations with Jerusalem Arabs. In a sense, this text has a flatness to it - just as the city can have this aspect - out of which I want to eventually focus upon the mundaneness and salience of the food that figures in it.

The third part of the paper - Bellum Juridicum - returns to the fraught context of Israel/Palestine where law and food not only convey their own everyday significance but simultaneously haul a teetering freight of culture and politics. This part of the paper should show a small fraction of the ways in which banalities such as food (and implicitly law) might open up (or not), like pop-up books, into dioramas of dispute and order.

Before I return to Israel/Palestine as a particular instantiation of the theoretical approach to food and law that I am advocating, and before I return the reader to the delectable offering of wares along the labyrinthine streets of Jerusalem's Old City in the first part, I want to take an excursion in the second (and next) part of this paper - Juridicum Promiscuum - through some of the dominant theoretical conundrums and promises of the burgeoning field of legal mixité studies. It 
is here that I want to lay out the central tension of this paper, which is a way of looking at mixed jurisdictions that forces us to take account of the dynamic that is the back and forth between merit-driven and integrity-driven judgments that go in to characterizing not just mixed legal jurisdictions, but all jurisdictions.

\section{JURIDICUM PROMISCUUM}

Food, or food metaphors, figure prominently amongst those legal scholars preoccupied with mixed legal jurisdictions. Nicholas Kasirer, in his article about legal education in mixed legal jurisdictions as a form of métissage, celebrates the move from scientific to culinary understandings of how differences mix. "Legal theorists and cultural anthropologists," he points out, "have independently proposed to move metaphorically from the laboratory to the kitchen" ${ }^{5}$ to explain competing views about pedagogy within mixed jurisdictions like Quebec, Louisianna, or Israel. Struggling to push both scholarship and teaching to focus more on the dynamics of exchange in mixité rather than on the static product of distant encounters, Kasirer feeds upon the image of the mixed legal system as minestrone on the stovetop, predicated on the "ongoing, dynamic interaction of the component parts of the whole."

Esin Örücü also draws food metaphors to speak to the diversity of the mélanges that are conjured when migrations (of populations and of legal institutions) stew and bubble with local populations and law. "When there is both legal cultural affinity and socio-cultural affinity," she notes,

[t] he elements unite to form a new compound. This can be depicted by the metaphor of a 'purée', indicating a blend so thorough that the constituent elements are indistinguishable and inseparable, the ingredients having been processed over a long period of time... However, when the movement occurs between systems of socio-cultural affinity but legal cultural diversity, then the elements do indeed mix but still retain their separate identity. Here the metaphor used is a 'mixing bowl. In the mixing bowl the ingredients are in the process of being blended. However, while the chopping and mixing goes on, a knowledgeable cook can still see the bits and pieces surfacing and sinking.... [W] here systems are culturally diverse both in legal culture and socio-culture we can talk of plural or dual law...This is reminiscent of an Italian style salad where though pieces are distinct, looked at through the glass of the bowl they are intermingled, above and below each other, a salad dressing covering each item... The last metaphor, the 'salad plate', resembles an English salad, the ingredients sitting separately and often apart, on a flat plate... This is the other end of the spectrum which starts with purée. ${ }^{6}$

4 Nicholas Kasirer, "Legal Education as Métissage" (2003) 78 Tul. L. Rev. 481.

5 Ibid. at 489.

6 Esin Örücü, "A Theoretical Framework for the Transfrontier Mobility of Law" in R. Jagtenberg, 
As rhetorical aids to lubricate our understanding of the nature of mixité, these food metaphors seem promising. And yet, they also reveal some of the very limitations that beset analysis of mixed legal jurisdictions.

While Kasirer wants to focus, in his work on mixed jurisdictions, on the $d y$ namic of contact between constituent parts and the experience itself of confrontation (an agenda for the study of mixed law that I emphatically share), the metaphor of minestrone offers something that is already cooked, already constituted, already set, ready to be consumed with no further ado.

Örücü's use of the food metaphor - the buffet of gazpachos, chopped salads and raw vegetables - though delightful and inviting, also tends to reproduce the taxonomic preoccupations of traditional comparative law that a focus on mixité seemed so perfectly poised to avoid. Each specialty, even the least fussed over and embellished, is a fully prepared dish, not represented by its constituent parts and not particularly redolent of the preparatory process, but by the whole that it represents on a menu. This takes us further away from Kasirer's alchemical moment of encounter and dynamic of contact that preoccupies the body of his article. The study of mixed legal jurisdictions, pursued along these metaphorical lines, seems more likely to reproduce what so many of us have come to see as the stale categories of comparative law, which are typically and unbudgingly structured around the heavyweights of Common law and Civil law. The potential within mixité appears to be similarly laid out as food stylists might, sculpting colours and shapes with the legal equivalent of cotton swabs, glue, and glycerine to fashion an appetizing re-presentation that looks (and typically is) too good to eat, a presentation of new congeries of detail.

That the food metaphors tend to focus on the final product of the mixing process rather than on the process itself is somewhat ironic for both of these scholars. Throughout their body of work, they are both keenly attuned to the fraught, unstable, politically charged and dynamic nature of mixed jurisdictions. That the metaphors they reach for (though proffered like sourdough starters to keep a leavening focus going for the next generation of comparativists) tends to the products of fixite rather than the processes of mixité may indeed be a feature of the object of study. There is a paradox at the core of mixed legal jurisdictions characteristic of most, if not all of them. This paradox, I would suggest, is not uncommonly, though sometimes implicitly, projected onto scholarly debates about mixité.

\section{A. Reification and Pragmatism in Mixed Legal Theorizing}

H. Patrick Glenn alludes to this paradox when he talks about a tendency towards reification amongst mixité scholars. ${ }^{7}$ And many of the contributors to the first World Congress on Mixed Legal Jurisdictions reiterate, at one point or another in their work, this same characteristic, namely a description of a moment of historical preoccupation, within mixed jurisdictions, with affirming and fixing and keeping flux at bay. ${ }^{8}$

E. Örücü \& A.J. de Roo, eds., Transfrontier Mobility of Law (The Hague/London/Boston: Kluwer Law International, 1995) at 10.

7 H. Patrick Glenn, "Mixing It Up" (2003) 78 Tul. L. Rev. at 79.

8 See (2003) 78 Tul. L. Rev., which has published all of the papers emanating from the World Congress's first conference. 
Glenn lays out his discussion about 'reification' as though there are two fundamentally distinct approaches to questions about beneficial versus pathological transformations within distinct legal traditions brought about by the introduction of particular legal propositions or institutions from another. The first approach is to assess the legal proposition on its merits to determine whether it will be felicitously transformative or not. The pedigree of the proposition is not relevant for determining what is or is not felicitous, or at least not preponderantly relevant. What prevails in determinations of merit are judgements about how a new proposition fits into and reverberates with the rest of the logical, semantic, and pragmatic features of the tradition. Preservation of the status quo tends to be regarded, on this approach, as retrograde and unproductively stultifying and insular, holding the tradition to the past for its own sake. Ideally, innovation is good because it enables the tradition to respond creatively to present circumstances and future dilemmas. This is the approach of merit driven incorporation on Glenn's account.

The second approach relies more heavily upon a concept of integrity hitched to the preservation of what has been historically distinctive about the tradition. It focuses first, in other words, on the tradition and how things have usually gone. The reliance of the second approach upon the virtues of distinctiveness tends, in Glenn's view, to push proponents to assess transformative value teleologically, one might say, in light of a more holistic purpose that is also being served by the semantic, logical, and pragmatic aspects of the tradition. The more holistic purpose would include such things as the distinctively cultural, linguistic, national, intellectual and metaphysical aspects that suffuse the tradition with human meaning. An innovation is good because it enables present circumstances and future dilemmas to continue to reverberate with and respond to cherished values of the community and its history. This is the approach of reification, on Glenn's account.

Glenn is fairly clear that theorists of mixité will only hinder and paralyze the evolution necessary for any legal tradition to thrive if they consistently harken to a past that, as he describes it, must be first reified (making it stiff and unwieldy) to be reproduced in the present and future (making the law stiff and unwieldy). As Glenn notes, reification is "a form of positivism, because the object of positivism is that of simply describing that which exists." If this ascription of positivism is somewhat unintuitive (i.e., if the affiliation of those who tend more to legal communitarian impulses with positivism seems counterintuitive), Glenn goes on to elaborate that in virtue of preservation being a good in and of itself, it confuses positive and normative philosophy. Legal value cannot be assessed on anything further than the ability of an institution to reproduce what has gone before. It is therefore purely descriptive.

Further, arguments flowing from a reification of the past inevitably disfavour cross-traditional persuasive capacity, given that each hankers for its own pre-contact integrity, further insulating each tradition from reason. Glenn is clear that, given these limitations, the only effective debate that propels jurists to intelligently assess the beneficial impact of transformations flows from debates on the merit. Being tied to a putatively integrated past hinders the ability of traditions to flourish and thrive. 
Both Kasirer and Örücü have echoed this position in their work, both ultimately favouring a move away from the nationalist, linguistic, and institutional purisms that have, at different historical moments, predominated in the legal systems that they examine (Quebec and Scotland respectively). They both prefer Glenn's merit driven model of judgment as a means of generating legal innovation.

And yet the work of both Kasirer and Örücü also includes detailed, historical material that implicitly and explicitly valorizes the distinctiveness of the (typically) civilian legal system as it has managed to hold its own against a dominant Common law standard.

Kasirer, in an article beautifully researched and co-written with J. M. Brisson, covers the history of matrimonial regimes in Quebec and how institutional alliance of the regimes with French civilian structures was tied to Quebecois nationalism. ${ }^{10}$ The mirroring of French regimes in Quebec family law - indeed the transformation of Quebec's civil code into a cultural icon by virtue of its aspiration to reproduce in high fidelity the law of the motherland - was used instrumentally by Quebecois nationalists as a way of distinguishing Quebecois culture from an encroaching Anglo-Saxon majority, particularly in the period of the 1920s. The Civil law and Civil Code became untouchable and unchangeable (and increasingly obsolete as a result) as they fulfilled a vocation to embody and reflect the identity of the Quebecois people.

Kasirer and Brisson's article ends up tracing later 'progressive' developments in Quebec's matrimonial regimes in the context of Quebec's Quiet Revolution in the 1960s. The evolution of the regimes is lent a 'progressive' hue partly because they are linked with the emancipation of women within Quebec society and the larger western world. Abolition of restrictions on married women's contractual rights and regimes that enforce the equitable division of property upon dissolution of marriage are institutional changes driven by the feminist movement that arose historically in tandem with Quebec's Quiet Revolution. The association of beneficial transformation with the emancipation of women is so consistently understood as a good in the western world that providing a history of changes appears to be mere descriptive sociology. This is a transformation that has the bedrock qualities of a hyper good in the western world, to use Charles Taylor's phrase. ${ }^{11}$ To question whether these changes are indeed 'progress' tags one as an outsider or a tiresome relativist. ${ }^{12}$ And Kasirer and Brisson do not spend much

10 J.M. Brisson and Nicholas Kasirer, "The Married Woman in Ascendance, the Mother Country in Retreat: From Legal Colonialism to Legal Nationalism in Quebec Matrimonial Law Reform, 1866-1991” (1996) 23 Man. L. J., 406-449

11 "Practical reasoning ... is a reasoning in transitions. It aims to establish, not that some position is correct absolutely, but rather that some position is superior to some other. It is concerned, covertly or openly, implicitly or explicitly, with comparative propositions." Compare (and conjoin) this passage to the following: "Even those of us who are not committed to so single-minded a way recognize higher goods? That is, we acknowledge second-order qualitative distinctions which define higher goods, on the basis of which we discriminate among other goods, attribute differential worth or importance to them, or determine when and if to follow them. Let me call higher-order goods of this kind 'hypergoods', i.e., goods which not only are incomparably more important than other but provide the standpoint from which these must be weighted, judged, decided about." Charles Taylor, Sources of the Self: The Making of Modern Identity (Cambridge, Massachusetts: Harvard University Press, 1989) at 72 and 63

12 The stance from which this transformation (the emancipation of women) is questioned as 
time elaborating upon why this is a beneficial transformation. Rather the fact that Quebec private law allowed itself to bend to the progressive call of the women's movement in the 1960s is taken as the backdrop for examining a parallel capacity within Quebec society to bend away from a sycophantic mimicry of French legal renovation.

Although there are many interesting things to say about the role that the emancipation of women plays in ascribing normative value to transformations within legal traditions, I want to focus on another somewhat more subtle way in which Kasirer and Brisson evaluate the transformation in matrimonial regimes that they describe. It begins with words like sycophantic and develops the theme through the use of criteria such as 'épanouissement' (an opening out or blossoming) and 'maturity'. These terms are not exactly associated with the merit-driven judgements that Glenn advocates, but they are closely associated.

The ability of Quebec legal reformers (through the Civil Code Revision Office tasked to overhaul the 1866 Civil Code of Lower Canada) to open themselves to the merits of other legal traditions, wherever they have sprung up, is taken, by Kasirer, as a sign that Quebec legal thinkers, and Quebec law, had matured; its very openness to alterity, even an historically dreaded Common law alterity, being a sign that it had consolidated its identity and shed a former crippling suspicion and anxiety about its ability to survive the dominance of the other. Words like 'maturity' and 'épanouissement' are of course laced with normative judgements - highly favourable ones. Like the equally vague and yet potentially devastating pair of terms 'appropriate' and 'inappropriate', they discipline and channel social behaviour. Describing Quebec's move towards a self-conscious legal creolization as a sign of maturity, bravely unconcerned about tying itself to a narrow nationalist past, is not descriptive sociology (or not merely) but also prescriptive and normative sociology.

A new identity is being endorsed with these ways of characterizing transformation. It is a bit of an odd identity because it is both associated with adulthood and with a more youthful spirit of adventure, with being simultaneously settled and yet ever ready to be unsettled, comfortably uncommitted in the way of those who finally feel at home in the world (sort of middle-aged and bourgeois). Ultimately this identity of maturity and openness has no more bedrock solidity than the evocative associations that it rouses - which is also the appeal of calls to resist assimilation and oppression that stirred the prior generation when conjured together with an elaborate history that delineates the threat. By pointing this out, I am not suggesting that the bedrock is not firm. I am only suggesting that it, too, is historically contingent.

Örücü also covers the period of suspicion and anxiety that Scots law went through, a period critical to its eventual identity as a mixed jurisdiction. Just as Civil law was wed to Quebecois nationalism as a component of the coat of arms on the shield against Anglo-Saxon encroachment, Civil law was deployed as a marker of Scottish identity. As in Quebec, during the first 'renaissance' of Scottish law after WWI, "the protection of "the churches, the education system and

beneficial in a way that leads to serious debate is these days most typically associated with cultures and legal traditions where it is not it is not taken for granted as 'progressive.' 
the law" gave form to the continuing belief in Scottish nationhood and identity." ${ }^{13}$ A projected integrity of Civil law, uncontaminated by Common law, was drawn upon by Scottish jurists as a standard by which to measure transformations. As Örücü notes about Scottish law's first renaissance, it "bears the marks of the purists, and in their struggle with the pollutionists they gave up being pragmatic but wanted to preserve one of the elements of this mix in preference over the other." ${ }^{14}$ Like Kasirer and Glenn, Örücü finds this puritanical approach stultifying for the legal tradition, endorsing, as an alternative, "choices made on merit rather than emotion." To renew itself, Scots law must no longer "hanker after the past". Like Kasirer and Glenn, whose very use of words like sycophancy and reification tips the descriptive balance in a new normative direction, words like purist and pollutionist are already poised to do the normative work of identifying beneficial transformations that have occurred and morally fortifying us for those that are to come.

\section{B. The Historical Contexts of Reification and Pragmatism}

Thus far this underlining of the normative heft of the values of emancipation and cosmopolitanism is not particularly novel. I should also stress, in addition, that I am not rejecting the stance that is advocated by these terms. I am, rather, pointing out that they may indeed arise at a particular historical juncture and acquire greater or less currency as a result of that juncture. The point at which a group can consider its past as sufficiently settled that it does not need to be hankered after may well be that point where the identity that the prior generation sought to shore up is sufficiently ensconced and at home in the world. In the common preoccupation of many mixite theorists, the dominance of the Common law world has been kept at bay by the agitation of nationalist civilians; indeed the fact that Civil law that survived in jurisdictions colonized by Common law not only renders the jurisdiction mixed, but is also drawn upon with pride as a significant model for the broader world of comparativists. Where mixed jurisdictions used to be the bastards of the comparative world, they are now the darlings. As Palmer points out (with some pride), "mixed jurisdictions are clearly becoming of greater interest in the wider world....As harmonization efforts and globalization trends continue, there is a greater need for accommodation between Common law and Civil law ideas and institutions....[T] he classic mixed jurisdictions, rather than Europe's stepchildren, are actually the forerunners of her future." ${ }^{15}$ A nonchalantly bold spirit of cosmopolitan openness and a colourful past of blasé familiarity and common mingling are stirring character traits for a new heroic identity.

I would suggest, out of the stirring and evocative use of terminology drawn upon by mixité theorists, that merit-driven judgement and judgements that call upon on the past are not really quite such disparate approaches to new legal

13 Esin Örücü, "The Judge and Jurist in Scotland: on the Verge of a Second Renaissance" (2003) 78 Tul. L. Rev. 89 at 94 [Örücü,, "Second Renaissance"].

$14 \mathrm{Ibid}$. at 95.

15 Vernon Valentine Palmer, "Salience and Unity in the Mixed Jurisdictions: The Papers of the World Congress" (2003) 78 Tul. L. Rev. at 3-4. 
propositions as Glenn suggests, but rather more closely wed to the same historical processes that gave rise both to the nation state and its current demise. Both are familiar rhetorical devices that are deployed at different times and for different reasons. A fair deal of the contemporary currency of the language of openness and maturity and post-nationalism comes, I would suggest, from the peculiar histories of mixed jurisdictions, particularly from the way they are predominantly set out in the literature as founded upon a tension between a dominant Common law and a fragile civilian tradition; and also particularly at the contemporary historical juncture where all state based legal systems (historically almost exclusively either Civil law or Common law) are losing their official lawmaking monopolies. I am hoping that if I can elaborate a little bit more on this process, then mixité studies may well be more securely on their way to focusing upon the agonistics of encounter rather than its products, as Kasirer, Örücü, Glenn, and many mixité theorists are pushing us towards. I will return to 'Israeli' food and Israel as a mixed jurisdiction once I have laid out this problematic.

\section{Legal traditions as Bullies}

Mixed jurisdictions are routinely characterized as those jurisdictions "at the intersection of Civil law and Common law"16 - a characterization that I (along with a growing body of others) find too narrowly restricted to a numbering system with only two values. I will address this issue later, but for now, I want to focus on one of the other recurring themes in mixite scholarship, namely that in virtually all mixed jurisdictions within this binary framework, the Common law is perceived as a dominant and at times oppressive force and the Civil law, in the majority of mixed jurisdictions, needs to struggle to affirm its identity and to shore up the civilianness of its institutions or risk being swamped in a Common law sea.

The only well-known writer (generally writing outside the mixité canon) who describes the vulnerability of the Common law in a jurisdiction overwhelmed by the Civil law is Pierre Legrand, writing against European codification on the civilian model. ${ }^{17}$ He struggles to shore up a deep and chosen Common law tradition against a shallow assault by a civilian sham cosmopolitanism that appears wilfully blind to the way in which a proposal to codify Common law is not a neutral institutional act, but rather a transformation designed to run roughshod over the distinctive mentalité of British Common law within the European context.

The bulk of other writers analyzing the intersection of Common law and Civil law point to the fragility of the civilian tradition and the tendency of the Common law to overwhelm the civilian institutions in its midst. Some mixité scholars seek to understand the procedural and substantive subtleties that seem to render this progression inevitable without the further buttressing of the Civil law. Others are more frank about the bald political underpinning of the ten-

16 Daniel Visser, "Cultural Forces in the Making of Mixed Legal Systems" (2003) 78 Tul. L. Rev. at 47.

17 Pierre Legrand, "Against A European Civil Code" (1997) 60 Mod. L. Rev. 44; Pierre Legrand,

"European Legal Systems Are Not Converging”" (1996) 45 I.C.L.Q. 52 
sion between the two systems. Smith, for example, one of the early thinkers on mixité, remarks in the Scottish context that "Common law influence prevailed, not necessarily on account of superiority in quality, but as a consequence of political supremacy.... The Anglo-American Common law has never been received voluntarily on account of its intrinsic merits alone. It has extended its influence through mandate, colonisation, conquest or cession." ${ }^{18}$

The recurring theme of civilian fragility can be seen in jurisdictions other than Quebec, and Scotland covered above. Max Loubser ${ }^{19}$ ties the turning of a tide of British imperial disregard for the civilian and Roman-Dutch law associated with the conquered Africkaaners "to the resurgence of Afrikaner nationalism in the aftermath of the Anglo-Boer War, the establishment of Afrikaans-language law faculties at Stellenbosch in 1920 and Pretoria in 1930, and the founding in 1937 of the Afrikaans-medium ... [Journal for Contemporary Roman-Dutch Law], with several other mainly Afrikaans-language legal journals to follow." ${ }^{20}$ The resurgence of Civil law in this mixed context was also a considered and self-conscious choice associated with the preservation of a beleaguered national identity. A.N. Yiannopoulos offers a literal lament voicing the same anxiety over the loss of a brilliant civilian identity in Louisianna in the face of insidious and overpowering, if not barbaric, Common law impositions and encroachments. ${ }^{21}$

Whatever the mixed jurisdiction, a running theme that each of these traditions seems to have wrestled with is the fragility of collective civilian identity in the face of a pervasively dominant and dominating Common law one. Put more generally, a recurring theme in mixité appears to be asymmetries of power between distinct social groups and the way that the law has been marshalled in that struggle. If legal traditions are mixed, it appears to be because proponents of the weaker tradition have wrestled with the problematics of collective legal identity in the face of an array of subtle asymmetries of power between one member of the mix and the other.

Israel stands out, perhaps, (within the binary mix of Common law and Civil law) in manifesting a more conspicuous nonchalance about the dominance of the Common law or the Civil law; a more conspicuously pragmatic choice to pick whichever legal institution or proposition holds greater merit in the circumstances. No doubt this nonchalance can be attributed to Israel's equal indifference to either as a colonizing force given that the rise of a Jewish identity associated with the state of Israel did not particularly see the colonial Common law of the former British Mandate as less of a threat than the Civil law from a viciously hostile Europe. And the legal traditions of Europe and North America tend not to be the alter that raises a spectre with Israel.

Food metaphorists Örücü and Kasirer, then, have company in referring to and

18 T. B. Smith, "The Common law Cuckoo has already laid too many eggs in the eagle's nest", Studies Critical and Comparative (Edinburgh: W. Green and Son, Ltd., 1962) at 90, cited in Kenneth Reid, "The Idea of Mixed Legal Systems" (2003) 78 Tul. L. Rev. 5 at 14

19 Max Loubser, "Linguistic Factors into the Mix: The South African Experience of Language and the Law" (2003) 78 Tul. L. Rev. 105 at 115

20 Ibid.

21 A.N.Yiannopoulos, "Requiem for a Civil Code: A Commemorative Essay" (2003) 78 Tul. L. Rev. 379 
analyzing a period of nationalist (typically civilian) pride within the history of diverse mixed jurisdictions. They also have company, however, in valorizing the identity of creolization and cross-pollinization. Even Yiannopoulous's Requiem for a Civil Code is answered by Hector MacQueen's plea that a future-oriented mixed law be not mired in (to use Glenn's term) a reified past. While the bulk of writers refer to a period of nationalist pride within the history of diverse mixed jurisdictions, just as many writers advance mixité as a new vanguard of both comparative studies and offer itself as a renewed source of pride. As MacQueen says, "Once upon a time, to say that the future looked mixed expressed the view of a pessimist; perhaps, at least in the context of law, it may become the characteristic outlook of the optimist."22

\section{Binary Opposition or Mobius Strip?}

These two groups of writers, proud of a distinctive past and proud of the distinctive contributions of mixité to the future shape of the comparative law world are often one and the same people. This leads me again to wonder whether Glenn's description of two distinct and divergent approaches to mixité is quite apt, or whether indeed these are not two aspects of the same phenomenon, perhaps at different historical moments, or called upon to do different tasks. There are several reasons to be suspicious of yet another binary opposition in mixité scholarship. The first is the fact that, as many mixite theorists point out, all legal systems result from a mixture of foreign and local elements.

Daniel Visser's comment that "[i]n one sense most of, if not all, the legal systems of the Western World are mixed, as almost any system that one cares to single out has been built up from a variety of disparate sources" ${ }^{23}$ is shared (also almost in passing) by many mixité theorists. This recognition of the open and dialogic nature of all cultural phenomena is quickly answered by the same metaphoric range of comprehension that Örücü struggles for above. The stale structuralist comparative law classifications into a binary world of Common law and Civil law clearly doesn't account for the multifarious phenomenon of exchange characteristic in those jurisdictions where encounters between the systems have been intense. Visser, following Vernon Palmer, responds to this taxonomic failure, however, by calling for a further set of subdistinctions: " $[\mathrm{t}]$ he fact that some systems are classified as mixed means that those giving these systems this appellation must have a certain measure of mixing or a particular kind of mixing in mind." ${ }^{24} \mathrm{He}$ recapitulates Palmer's focus on "the specificity of the mixture" in a way that echoes Örücü's range from purées to salad plates, descriptively quantifying how much blending between the Common law and Civil law has gone on. This refined taxonomy built upon comparative law's already stark bifurcation of legal phenomena seems to compound the failures of traditional comparative law, not cure them. If the term "mixed legal jurisdiction" (or "mixité") was invented, as Palmer points out, in recognition of a failure of classification among legal

22 Hector MacQueen, "Looking Forward to a Mixed Future: A Repsonse to Professor Yiannopoulos: (2003) 78 Tul. L. Rev. at 417-18

23 Visser, supra note 16.

24 Ibid. at 46 
families, perhaps the solution is not the addition of a new intermediary classification, a 'third family of law', but rather a revisiting of the practice of classification altogether. This is where, I would suggest, food metaphors tend to represent more of what food stylists do than the practices of gourmets and gourmands (along with fast order chefs, exhausted housewives, and the hungry hordes).

The reliance of mixité scholars upon an already impoverished binary taxonomy is one reason to be cautious around the apparent choice between merit driven and reification coloured ways to distinguish the advantageous from the pernicious in legal propositions. Another reason to be wary is that doing so may distract us from the very dynamic and dialogic moments of encounter within all legal traditions that Kasirer is hoping the next generation will focus upon. If the term was invented, as Vernon Palmer points out, in recognition of a failure of classification among legal families, perhaps the solution is not the addition of a new classification, but rather a revisiting of both the practice of classification and the kinds of things that seem to be going on when different strategies - reification or pragmatism - are invoked.

My concern here also comes out of the recognition that "most of, if not all, the legal systems of the Western World are mixed." It comes out of recognizing that the kind of tension that Glenn articulates about reification and merit also has a counterpart within both of the separate Civil law and Common law worlds. It is not, in other words, a tension that only characterizes debates and tensions within mixité.

\section{E. Hermeneutic and Grammatical Readings as a Mobius Strip of Ideology: An Analogy}

The question about whether jurists should be driven by the merits of an innovation or whether they should be responsive to the course and trajectory of past innovations has an analogue in an article by Mitchel de S.-O.-l'E. Lasser in a 1997 Utah Law Review article. ${ }^{25}$ The overlaps in the tension that he sets up between hermeneutical and grammatical readings of texts are not completely coincident with Glenn's tension between merit and tradition-driven judgments, but they are informative nevertheless, particularly as they come in a comparative law article about outsider perceptions of the Civil and Common law traditions respectively and the tendency of outsiders to reify a foreign legal tradition in much the same manner of the nationalists and purists described by Glenn, Kasirer and Örücü.

Lasser begins his article by talking about the proclivity of American comparative law writers to set up French civilians as a rigid formalist foil for American pragmatism. Comparativists John Dawson and John Merryman concentrate, in their writings on Civil law, on salient features of French civilian judgements such as the absence of concurring or dissenting opinions, the absence of reference to prior court decisions, the absence of reasons for judgment, and the impersonal, unsigned, highly stylized structure of French judicial decisions. These evident features of French Civil law lead Dawson and Merryman to characterize the

25 Mitchel de S.-O.-l'E. Lasser, "Comparative Law and Comparative Literature: A Project in Progress” (1997) Utah L. Rev. 471 
civilian system as highly formal and the relationship between judges and the law, projected and organized by an overarching civil code, as a mechanical one. Judges are merely the vehicle of the law, using an absolute minimum of discretion and drawing upon no extraneous sources for judgment apart from the dictates of legislation. In this regard, French civilians are the formalist other to American judicial pragmatism, which tends to present itself (especially in the period during which legal realism held sway in the academy) as supplely responsive to the social, political context in which the law operates, both historical and contemporary. American judicial discourse is characterized by personalized, actively engaged judges infusing legislation with meaning by actively interpreting it in light of the surrounding actualities in which it was crafted and will be implemented.

Lasser begins with what he characterizes as this naïve portrayal (of each tradition) and carries out ethnographic research within the French court structure. He speaks to a diverse range of French jurists, in their own language (legal and mother tongue) to decipher the particular emphases that insiders put on the objects, ideas and institutions that they use. He accesses a wide range of reasonable and committed legal actors who make sense of and critique their own legal system to arrive at varied, nuanced, and often critical understandings of judicial decision making. He listens for multiple and conflicted voices about the salience and relative importance for insiders of features of French judicial decision making. He also attends to the actual practices and hidden facets that structure French judgments rather than the public face of legal formalism that is presented also to insiders as orthodoxy. In this manner he habituates himself to both the contingency and apparent necessity of French legal discourse through tacking back and forth between official presentations and heterodox understandings.

Where Dawson and Merryman projected a duplicitously hidden and masked pragmatism upon French formalism, Lasser uncovers institutional arrangements, principally in the functions of the Magistrat and Avocats-Général, where the kinds of socially responsive, historically sensitive, jurisprudentially attuned, contextually open features that Dawson and Merryman attribute to American judicial discourse have a home within French legal processes.

Lasser then turns his analysis to the putatively supple, pragmatic, and more unabashedly personalized style of American legal judgment and uncovers a backgrounded formalism that mirrors the backgrounded pragmatism of the French system. Where pragmatism and formalism are bifurcated in two separate institutional spheres for the French, Lasser points out that the American tension between these two discourses is located within the structure of the judicial opinion itself. The ubiquitous judicial test generates an imbedded, rule-driven formalism that displaces the apparently controlling primary text (for example statute or constitutional clause) which allowed for the first play of contextual, personalized, socially responsive and flexible judicial interpretation.

So far Lassers' analysis is intriguing of its own account. But it is the further analysis that he generates from this layout that I want to borrow to rethink Glenn et al's opposition between merit-driven and 'reified' decision making within mixed legal traditions. I am hoping that it becomes apparent, out of this analysis, why Israel/Palestine as a mixed jurisdiction (though not as conceived 
by current theorists of Israel's mixité) is a potent field in which to focus upon the dynamics of encounter that Kasirer is advocating for mixité studies.

Lasser borrows from linguistic theory to step aside from the formalist/pragmatist opposition that comparativists had used as a heuristic and asks us to focus instead upon grammatical and hermeneutic readings of texts, conjoined with ideology, to understand the complex presence of both approaches within legal traditions and the seeming inability of American comparativists to apprehend this complexity and richness within their counterpart legal tradition.

Grammatical readings of text posit the possibility that reading can consist of no more than direct and unmediated application of the language of the text. Ostensibly, French judicial practice is grammatical in nature: judges mechanically apply the text without further need of interpretation deriving from any number of contextual sources. Hermeneutical readings, on the other hand, are oriented to interpreting the text in terms of historical, political, social, economic, religious, or other theory; in light of a larger background of thought and experience in which the text makes sense. Ostensibly, American judges attends to these interpretive practices when they recur to prior jurisprudence, or the subtleties of the context in which the law was crafted and in which it will be applied.

Lasser argues that each respective legal tradition has an official portrait that emphasizes, for insiders and foreigners alike, one or the other of these approaches to texts as representative of the core of the system's legal sensibility. But each tradition also, of necessity Lasser would argue, has unofficial locales where the alternative approach is embraced and nourished. For the French, this locale is dispersed into alternative and complementary institutional functions where contextual interpretation is given freer reign; for the American the space for grammatical readings is relegated to the binding and unmediated nature of judicial tests.

Both approaches are, of necessity, present in each tradition, though more or less officially fore-grounded, because certainty and flexibility, stability and social responsiveness, are indispensable components of each legal traditions (indeed likely of all legal traditions, though Lasser does not explore this point.) Grammatical and hermeneutic modes of reading do not, and perhaps cannot, Lasser argues, exist independently of one another.

Although different combinations of modes of reasoning characterize different legal traditions, along with different locales for each to flourish, the particular configurations of discourses around these modes of interacting with texts arise in historically and culturally contingent ways. An official emphasis on one or the other mode of interacting with texts will reveal, to the legal ethnographer, a critical aspect of the discrete legal sensibility of each - the public, orthodox, and ideological presentation of the tradition to itself and to outsiders. But failing to perceive the interplay between the orthodox and doxic components of a form of life, the tension between the ideal representations and actual constitutive practices, would generate the kind of thin comparative analysis that Lasser accuses Dawson and Merryman of producing - analyses that, Lasser points out, reinforced their own particular, historically and culturally contingent, ideological needs at the time. 


\section{F. Applying the Hermeneutical/Grammatical Analogy to the Mobius Strip of Identity/Pragmatism}

What Lasser lays out with his description of grammatical and hermeneutical modes of legal reasoning and his highlighting of the ideological and contingent sources for favouring one or the other in official portraits of a legal system does not exactly fit squarely with how I want to use his analysis in the context of this paper. What Glenn calls merit-driven judgments does not clearly line up with either grammatical or hermeneutic readings of texts. I suspect Glenn would argue, and Örücü would concur, that merit-driven judgments will sometimes coincide with a strict and direct application of a legal text to an immediate situation and will sometimes draw upon the larger social, political, and historical context in order to arrive at a just or pragmatic resolution. Given that Glenn describes the tendency to reify a tradition's past for immediate reproduction as a positivist intervention, I suspect he might also see such a maneuver as grammatical - the reified text requires unmediated application without persuasive influence invading from a context extraneous to the tradition. However, given that the arguments from a 'reified' national, linguistic, or cultural past tend to insist that this background impinge upon how texts are immediately interpreted, it is easy to see how this approach might correspond quite easily with hermeneutical readings. Judgments that seek to reproduce the past can be considered socially responsive - with responsiveness directed to a tension between an embattled group that seeks to preserve and reproduce itself, and a dominant group that seeks to prevail by introducing its sensibility interstitially into the form and content of judgments. In other words, it's not easy to see how Lasser's analysis is echoed in the tension between pragmatism and reification (or identity politics) that Glenn sets out.

The overlap that I want to lay out comes more from a sense of the historical and cultural contingency of legal traditions presenting themselves as focused on merit-driven judgment as opposed to what I would prefer to call integrityfocused judgment (rather than reified). Just as grammatical and hermeneutic modes of reading do not and cannot exist independently of one another, so merit-driven and integrity-focused judgments do not and cannot exist independently of one another. Each legal tradition, Common law and Civil law, independently of each other, has known moments, extensive or not, where reproducing the past is vital; where the integrity of particular judgments is dependent also on the particular judgment being consistent with an established integrity in the law, drawing upon a prior community of practitioners and jurists. As much of the comparative literature on legal transplants has revealed, the maneuver of creating a legal identity self-conscious of its contours, in opposition to a distinct legal other, self-conscious of the other as a foil (good or bad) is a familiar one.

Each has also known moments when the overall identity and consistency of the tradition is not foregrounded, but emphasis is placed, rather, on how to proceed in this particular situation.

\section{G. Connecting Lasser to Glenn through Wittgenstein}

An excursus through a passage from Ludwig Wittegenstein (familiar to jurisprudence) should illuminate clearly the links between hermeneutical and grammatical readings and the merit-driven and integrity-focused judgments. The passage is meant to trouble our understanding of what it is to follow a rule (an 
arrow, for example, or a statutory section). Does the rule itself contain all the necessary direction for how it is to be followed (does it operate grammatically, driven by its own merit) or does it require a further step of interpretation to be operative (does it of necessity require a hermeneutic intervention, drawing upon a higher order set of rules derived from, for example, past practice)? "A rule stands there like a sign-post," Wittgenstein starts.

- Does the sign-post leave no doubt open about the way I have to go? Does it shew which direction I am to take when I have passed it; whether along the road or the footpath or cross-country? But where is it said which way I am to follow it; whether in the direction of its finger or (e.g.) in the opposite one? - And if there were, not a single sign-post, but a chain of adjacent ones or of chalk marks on the ground - is there only one way of interpreting them? - So I can say, the sign-post does after all leave no room for doubt. Or rather: it sometimes leaves room for doubt and sometimes not. And now this is no longer a philosophical problem, but an empirical one. ${ }^{26}$

Wittgenstein's assertion that this is an empirical question is striking - and also relevant for how to distinguish beneficial from pathological transformations within legal traditions when confronted with a new legal proposition. Also relevant is his assertion that sometimes the arrow or sign post leaves no room for doubt (i.e., can be read grammatically) and sometimes not (calling for hermeneutic readings).

An arrow on its own ("the dead line on paper") in a sense, cannot point on its own. This is a reality comparativists are familiar with. When Harry Barker points out that "the practice of law is difficult enough of itself without adding to its difficulties by obligating its practitioners to find their way through its anfractuosities in several languages", he underlines, in those implied difficulties, how reading a legal text, either in one's native language or, more insurmountably, in a foreign tongue, is not sufficient to understand how it operates. ${ }^{27}$ Painstaking familiarity with the way that a particular legal community uses and makes sense of the text points to its meaning and significance. The text on its own will not do that. The novitiate or outsider is bound to blunder and take miscues from isolated legal texts, uninformed by how the community that uses the text infuses it with meaning through use, through disuse, and through creative usage. And yet, for those who have become proficient and fluent in the text's significance and meaning, the text does indicate how to go on, how a particular situation should be read in its light.

For an outsider or a novitiate, the text is relatively inert (animated only to the extent of an overlap with ordinary language - and then not always) without an understanding of the conventions and practices that a community of practi-

26 Ludwig Wittgenstein, Philosophical Investigations (Oxford: Basic Blackwell, 1978) at para. 85.

27 Harry Barker, "Black Languages and the South African Courts", Opinion in De Rebus (July 2002) cited in supra note 16 at 42 
tioners have established as normative. An insider also, in the event of perceived need to re-affirm the text's significance within the practice of those who have painstakingly established the merit of a particular approach, has self-conscious awareness of how those conventions and practices need to be marshalled and affirmed. The historical and culturally contingent conventions (constitutive of a practice) about how to read a text need to be learned in order for the text to be more than inert (and of course, working backwards, the conventions of a mother tongue also need to be acquired for words to be animated such that an arrow points "in the application that a living being makes of it". ${ }^{28}$ ) Given the historical and cultural contingency that mark a practice, the importance of an empirical, rather than philosophical (or indeed wholly merit-driven, i.e., without recurrence to the practice) exercise becomes apparent. The text only makes sense within this kind of a context (and hence sometimes requires hermeneutic readings).

Once proficiency has been acquired, however, and the senses and sensibilities accordingly refined, then following the arrow is not done randomly. Nor does the arrow need to be interpreted at every juncture. The rules do not fall apart. The text is followed in the way that the proficient have learned to follow them - and it is the text (the "dead line on paper") that tells one how to go on. Sometimes the arrow or text or rule leaves no room for doubt. The anfractuous streets lead comfortably, in a familiar way, to a destination - grammatically, so to speak. But the 'sometimes' in that sentence also intimates that it will not be determinable, in advance, as if by a rule, when grammatical readings are appropriate rather than hermeneutical. It will not be determinable in advance when a grammatical reading will be a pathological interpretation and when it will be a beneficial one. Sometimes the rule (the dead line on paper) will tell us that the wrong direction has been taken. And sometimes the practice surrounding the rule will. Some grammatical readings don't bear the mark of a practitioner who has mastered the practice but rather the mark of one who is timid and inexperienced and still mechanical in their practice. ${ }^{29}$ Similarly, some hermeneutical readings bear the mark of one who does not yet know the significance of a doubt, someone whose transgressions appear juvenile and pretentious, someone does not yet know how to deftly call upon the resources of the tradition and play with them.

\section{H. Application to Identity/Pragmatism Tension}

A masterful hermeneutical reading can convince us that the most simple of grammatical rules is fraught. Extraordinarily convoluted and complex readings can distort the clarity and resolve that the situation calls out for.

Just as one cannot know in advance whether grammatical or a hermeneutical reading of a text is called for, similarly it must be premature to determine as a

28 This is a slight distortion of paragraph 454 of the Philosophical Investigations which reads, in part, "The arrow points only in the application that a living being makes of it." See supra note 26 at para. 454.

29 I am reminded of Ambrose Bierce's definition of a lawyer: One skilled in circumvention of the law. The Devil's Dictionary (USA: Oxford University Press, 1999) (Also relevant is his definition of logic: The art of thinking and reasoning in strict accordance with the limitations and incapacities of human misunderstanding). 
rule that merit-driven (pragmatic) judgments and incorporations are timely now, are mature and open, and will generate a profluence of beneficial transformations within a legal tradition. Some of those pragmatic merit-driven judgments will only be apparently merit-driven and will mask an unsophisticated grasp of the complex and delicate tapestry of conventions that have been painstakingly groomed into their contemporary form. Some of those pragmatic merit-driven judgments will fail as they too narrowly reproduce a formal and positivistic understanding of the text's (or legal institution's) significance, leaving little room for apprehending the full resonance of how an incorporation interacts with other elements of the tradition. Some of the pragmatic merit-driven judgements will fail for being oblivious to the ways in which a more dominant tradition has cleverly inserted its own contingent criteria of proficiency and competence in the place of one that was otherwise sufficient, despite its seemingly arbitrary and historically accidental provenance. Some of them will fail for any of the multifold ways that grammatical readings of texts are inadequate to the task at hand and are inadequate unto themselves.

And, of course, the same set of problems could be attributed to either an overly hermeneutic emphasis in approach; to one too emphatically focused on the overall integrity of the tradition at the expense of innovation, or one focused on contextual responsiveness and flexibility at the expense of the certainty and predictability that comes from a body of determinations made in a prosaic and straightforwardly grammatical way.

It starts becoming apparent (to me at least) that determining what is meritorious and what is not is by no means as straightforward an exercise as Glenn or Örücü or Kasirer were intimating. The 'maturity' of openness to alterity is no longer self-standing virtue when the bonds of the community are under threat and failing. Pragmatism, or 'what works', will not be determinable (or will not always be) in advance of assessing (in elusive normative terms) the impact on the overall tradition. And assessing the impact on the overall tradition (more a commitment of purists and reifiers - to use Glenn and Örücü's language) will not be possible without make elusive normative assessments of whether or not something 'works' in a particular situation.

Just as the French and American legal traditions that Lasser conjures present an official portrait both for insiders and for outsiders, one that respectively portrays the core of the tradition as grammatically or hermeneutically focused; and just as, stemming from the necessity of practices to sometimes rely upon one approach and sometimes another, but never exclusively one or the other; and just as each respectively has struck a balance between orthodox, doxic and heterodox practices that is relatively settled, contingent, relatively fluid, and in many ways historically accidental - so too will practitioners within mixed jurisdictions, for historically contingent reasons, sometimes feel sufficiently indifferent to, or settled about, or confused about the integrity of the overall practice to emphasize merit-driven as opposed to integrity-driven responses to legal propositions. And sometimes, again for reasons that can be empirically (ethnographically I would say) apprehended, practitioners within mixed jurisdictions will feel sufficiently settled or confused about the integrity of the overall tradition that they will be hesitant to accept a merit-driven argument for incorporation difference at face value, or alternatively propelled to accept it because it appears to 'work'. 
In neither event is there a way of always knowing, in advance, what will be a beneficial and what a pathological transformation of the tradition. Although I agree, for empirically accessible and historically based reasons (themselves simultaneously descriptively and normatively laid out), that reforms to Quebec's matrimonial regimes through incorporations from other jurisdictions (including the dominant surrounding one located next door in Ontario) through attending to how meritoriously the institution interacted with the needs of newly emancipated Quebec women manifested a beneficial transformation within the Civil law of Quebec, this assessment is not a blanket endorsement for all incorporations, regardless of the particular historical configuration of Quebec Civil law. Openness, in other words, is not a stand-alone virtue, no matter how often the concept is conjoined with other normative terms such as 'maturity'. That it works' will never be something that can be determined for all incorporations in advance outside of a combination of grammatical and hermeneutical arguments on the point. And both grammatical and hermeneutical arguments, as Lasser pointed out in his article, will be marshaled by ideology and the political interests that are met by presenting something as the official and orthodox way things are done. And it will not be possible, in advance, to distinguish which arguments are merely ideological, attempting to assert a new or old orthodoxy by referring to merit or pragmatism, or the inviolable core of the tradition; and which are dead-line-on-paper efforts to follow the integrity of the tradition in ways that will work best in the circumstances.

What I have laid out suggests a far more unstable and (in a way that I will qualify shortly) historically sensitive account of mixité than has been fully manifest in the potential of the subject - though Kasirer's admonition to focus on the dynamics of the encounter between traditions is salutary. I have argued that Wittgenstein's at times vexatiously equivocal point that a rule 'sometimes leaves room for doubt and sometimes not' (both unsatisfying for its lack of resolution and gratifying for its healthier embrace of the uncertainty in all things human and social) should be applied to understanding the nature of mixité in those jurisdictions that are now commonly recognized as mixed (Quebec, Israel, Louisianna...). Sometimes it would be healthier for a legal tradition to be open to innovations 'from away' and only focused on what is meritorious and 'what works'. And sometimes not. And this is not a philosophical problem, but an empirical one.

\section{Rendering Mixité Studies more Dynamic}

In any event, it should also be apparent from what I have laid out that the same approach - looking ethnographically for the way the tension plays out between grammatical and hermeneutical, or merit- and integrity-driven motivations within a legal sensibility - does the same kind of work within Common law and Civil law traditions independently as it does within studies of mixité (indeed Wittgenstein's investigations have long been familiar aids in jurisprudential studies).

This no longer allows the problematic of mixité to remain a taxonomic one. It's not really sufficient to point out that "most of, if not all, the legal systems of the Western World are mixed" and move swiftly on to insist that the specific qualification of 'mixed' must be coupled with "a certain measure of mixing or particular kinds of mixing in mind". It really is not sufficient to look at mixed jurisdictions as stable givens (the soup already cooked, the purée already blended) 
with sufficient combinations of discrete elements to occupy that specific corner of the comparative menu. As the very exercise that generated a 'new family' of legal tradition for comparativists to compare has made clear, the classification founded predominantly on a bifurcation between Common law and Civil law is arbitrary and itself historically contingent (typically contingent upon the empires established just prior to the $20^{\text {th }}$ centuries push towards decolonization) - though no less heuristically useful for that.

The problematics of mixité (even just for example the tension between meritand integrity-driven judgements) characterizes all legal traditions, just as the proper balance between grammatical and hermeneutical approaches to texts surfaces as a conundrum in all traditions. What is far more interesting, to me, than the emergence of a new intermediary taxonomic unit (a new 'family' of law with its own peculiar sources, divisions and concepts, and common historical evolution) is the way that mixite presents itself as an issue that cross-cuts all taxonomic orderings. What the now conventionally accepted (though loosely and also contested) 'mixed jurisdictions' (those founded on a blending of Common law and Civil law) lend to our understanding of that problematic are striking examples of the multifarious ways in which hermeneutical and grammatical readings, or pragmatic and integrity-driven arguments, are deployed in situations where ideological dominance and orthodoxy is, or has been, hotly contested; where due to familiar accidents of history such as conquest and colonization, a period of cultural and linguistic resistance and or nationalism figures prominently, creatively, and often poignantly in discussions and debates about the nature of law.

The promise of mixité is not so much a New Jerusalem, a place where Common law and Civil law peacefully cohabit, a shining beacon for the European Union and other by-products of globalization, but rather a way for comparativists to understand the processes that constituted the old, mundane, actual and anfractuous Jerusalem, however its jurisdiction is construed.

\section{J. Mixité as an Empirical Problem}

The reason that I indicated that the promise in mixité is 'in a qualified way' historical is also captured in Wittgenstein's point that "sometimes [a sign post] leaves room for doubt and sometimes not. And now this is no longer a philosophical problem, but an empirical one. ${ }^{30}$ By the word 'empirical', I do not take it that Wittgenstein would say that one could simply read the evidence as one would read a text and the evidence would provide a clear sense of how and why and when a sign post leaves room for doubt and sometimes not. Indeed that 'grammatical' reading of empirical evidence falls prey to the exact same problems that plague exclusively grammatical readings of sign posts. The investigation (and investigator) is more problematically caught up with the grammatical/hermeneutical conundrum.

And yet, sometimes empirical accounts (historical in the context I am talking about) will coincide with grammatical readings of the evidence, and sometimes not. I don't only mean by this to emphasize the by-now mundane point about reflexivity. I mean instead to suggest that the whole enterprise of investigat-

30 Supra note 26 at para. 85 . 
ing historical accounts is wrapped up itself in an historically contingent mix of stability and uncertainty, common sense and transgressed understandings, unquestioned premises and bold new normativities. Kasirer's use of the emancipation of women in Quebec of the 1960s as more or less taken-for-granted social good to foreground an analogous emancipation of Quebec law from a French motherland, thereby favoring the normative value of openness (underlining its normative value by calling it maturity) provides an excellent example of this empirically rooted, relatively stable and settled approach to the offering of new normative appraisals of the virtues of openness and hybridity. Once the value of openness has settled as a virtue (as it seems inclined to do amongst proponents of mixed jurisdictions who laud their subject as at the vanguard of comparative studies) then a new way of assessing merit (deploying a new integrity: maturity) will be fully incorporated into the horizon.

If one were to conduct an empirical investigation into when and how and why, and by whom, in particular societies, rules were sometimes followed grammatically and sometimes hermeneutically, sometimes according to pragmatic arguments, sometimes according to arguments that harken to the integrity of the tradition, such an investigation would indeed need to look into particular historical configurations and events analogously to the linguistic study of the odd shapes of a language to an outsider.

There is also a trend, however, in mixed jurisdiction studies to look at these settled traits of mixed systems, as though each 'system' were a discrete and isolated whole. This kind of analysis can also generate historical studies, sometimes reliant upon the same kinds of chronologies that a history focused on fluid and more or less unstable processes would generate. Kenneth Reid alludes to this style of thinking about mixité when he notes that "a striking characteristic of mixed jurisdictions, viewed historically, is their mutual isolation...if "family" is the correct term, it is a family in which the members were, for many years, estranged and often hardly aware of each others' existence." The tendency then arises to re-group and categorize all of these discrete "systems" (because estranged, geographically and through colonization) as the fractured parts of a whole singular phenomenon, with a "developed body of mixed jurisdictions law [and] a literature articulating shared ideas and concerns." ${ }^{\prime 31}$

Örücü manifests a bit of this tendency to veer towards a trait-based historical analysis of particular mixed jurisdictions. "All mixtures differ," she points out, "in the way they have been formed, as their histories show". From this abundance of distinctiveness arises a temptation to list off and categorize those differences as discrete sets of settled distinctions, threatening an agenda otherwise devoted to understanding mixité as a dynamic phenomenon.

When I say, then, that mixité studies promise to offer productively destabilizing ways of generating historically sensitive accounts of legal traditions, I don't mean that the taxonomic inclination to depict new structures and categories should simply be aided by retrospective analysis. Describing something as gazpacho-like and something else as purée-like doesn't really do the work of sussing out the sometimes this and sometimes that of the matter; what rather seems to

31 Reid must be suggesting this proposal somewhat tongue-in-cheek, I imagine. Reid, supra note 18 at 7 
be required is a sensitivity to the historical tensions between official and unofficial uses of grammatical or hermeneutic readings, to the moments in history when openness is lauded as a virtue or deplored as a form of subservience, to the irritants that prompt integrity and pride to recur as themes rather than tolerance and a hunger for alterity.

The Common law and Civil law traditions, then, are also independently about mixité, about the healthy and/or troubled mix of necessity and contingency that characterizes all forms of human activity, including law. Mixité, then, is not really about depicting the features of a third family of law. It is rather a core fulcrum of comparative studies, as the long standing debate about legal transplants suggests. Studying the processes of mixité (perhaps in particular in locales, such as the classical 'mixed jurisdictions', where the process of mixing is difficult and conflicted and linked to a complex range of collective goods) should long ago have taken over as a way of doing comparative work; as a way of getting away from (not compounding) classifications and taxonomies.

\section{K. Ethnographic Accounts of Mixité}

This brings me to the last comment I want to make about Lasser's work within the French legal system. As Wittgenstein's allusion to empirical problems suggest (and is suggested in general in his recurrent admonition to "look and see"), understanding the subtleties of the places where a form of life has settled into a stable practice and where it seems more open to debate and innovation, or getting to the point of understanding where and why official portraits are undermined or shored up, requires something different than either devising a taxonomy or setting out an agenda of preferences for values such as pragmatism or merit or openness. It requires, rather, the kind of ethnographic investigation that Lasser launched upon in France.

In order to uncover a sense of the contingency and necessity (both apparent and seemingly incontrovertible) of native legal discourse, Lasser sought to go beyond the public face of the tradition, one that can be captivating to both outsiders and insiders alike. Instead, by inhabiting the world of French legal practice, he slowly habituated himself to the anfractuous language of French law, talking to insiders, attending and participating in the intricate workings of the practice. He listened to the multiple voices of reasonable and committed legal actors who routinely make sense of, and critique, their own legal system.

As I suggested above, this was not merely a process of reading from the evidence, but was guided by a prior sense that necessity and contingency (or grammatical and hermeneutical readings in Lasser's case, or merit- and integritydriven judgments in Glenn's case) both are mutually indispensable components of grasping a meaning or making a judgment. And though the groups Lasser investigated tend to present things as being primarily one or the other, he was curious about exactly how both are present in different places, and why, and who wants it to be so. Under the auspices of this kind of empiricism, it's difficult to perceive the other (whether a mixed tradition or not) as a monolithic and static object of analysis.

This approach to alterity (which is also an approach to self) would be well poised to get at the dynamics of encounter with which Kasirer (and I) would prefer to supplant taxonomies of mixité. In the first place, there is a hermeneutic 
dynamic at the very heart of ethnographic enquiry that ensures that the results of investigation will reflect the ever shifting historical processes set in play. This is the omnipresent ethnographic preoccupation with how much of the settled parts of self have skewed the perception of salience in the other - a dynamic of inquiry that simultaneously unsettles the stability of prior arrangements as self and other become self-conscious of alternatives through the process of inquiry.

The approach is also tonic because in the attempt to understand why a particular configuration of necessity and contingency has arisen as it has (or 'who wants it to be so?' and 'what's at stake?'), the ethnographic enterprise that Lasser embarked upon seems better equipped to deal with the constantly shifting ways that ideology interacts with 'the way things are done'.

And this approach overall occurs to me as something that could be instructive in expanding our understanding of the classically mixed jurisdiction of Israel, but perhaps more important, also instructive in understanding the phenomenon of mixité itself. I say this particularly because the taxonomic model applied to Israel seems so intuitively ill-equipped to describe the dynamics of encounter in that region that are so prominent in the world's imagination (no doubt overly prominent) as to be conspicuously absent in taxonomic accounts.

A focus on Israel's complex and often anguished mixité makes it very difficult to ignore the tension-filled and warring dimensions not infrequently characteristic of legal mixing - exactly where mixed legal studies would prefer us to focus on settled mixed jurisdictions, on places where jurisdiction and territory are no longer so openly in dispute. The rawness of Israel's bellum juridicum - or at least the rawness in evidence when we refuse to limit ourselves in our wandering to the comfortable settling between civil law and common law in Israel's history - allows us to revisit the historical moment in most mixed jurisdictions when bellum gave surviving mixed jurisdictions their leading characteristic.

\section{BELLUM JURIDICUM}

\section{A. An Ethos in Each Banal Transaction}

A recurring theme in writings on mixité - indeed one of the themes that Vernon Palmer notes is "distinctively "mixed jurisdiction" and typically receive[s] no attention in other forums" - is that of bellum juridicum. The coinage of the Latin phrase appears to have been fashioned by Afrikaners in the last century as a summation of their struggles to consolidate the jurisdiction of Roman Dutch Civil law against the encroachment of colonial British Common law in a manoeuvre that was simultaneously merit- and integrity-driven; aiming simultaneously to "create a more transparent and thus predictable system through a thorough organization of the law"32 and to entrench cultural and political identity.

Whatever the coinage of the synoptic Latin phrase bellum juridicum, the conjunction of serious legal debate with the struggle to preserve the hegemony of one legal tradition over the other fairly consistently characterizes historical struggles endemic to most, if not all, of the classical mixed jurisdictions. The tense apprehension of mundane legal manoeuvres as constitutive of a larger cultural struggle appears more prominently in mixed jurisdictions, no doubt reflecting histories more fraught with intra-collective tension. What would be commonplace ex-

32 Visser, supra note 16 at 56 
changes and transactions in a pacific setting, carry a freight of perils, often painstakingly itemized in a manner that perhaps only a lawyer would find intuitive.

This injection of integrity focus and identity politics into even the most prosaic of interactions is itself peculiarly akin to an ethnographic sensibility. The ethos of each banal transaction is exhaustingly summoned to mind in way familiar to the ethnographic field worker. In the case of the committed civilian in a Common law dominated context, the insider is ever and simultaneously alert to the way that a manoeuvre resolves a dispute at the same that that resolution fits within a larger legal sensibility. This struggle to stand outside of the tradition to apprehend its inner logic while apprehending how the inner logic works in particular circumstances is akin to what Lasser did in his study of the French legal system.

As I have noted above, this state of simultaneous alertness to both particular and general ramifications is characteristic of those most proficient within the Common law and Civil law independently, i.e., it is a phenomenon that runs through not only mixed jurisdictions. And both traditions are riddled with moments where the integrity of the whole was renewed or constructed against a real or imagined foil. The more persistent proto-ethnographic acuity within mixed jurisdictions, however, seems to be more honed, or perhaps slightly differently honed. Perhaps the intriguing difference for mixed jurisdictions is the more intensely self-conscious focus not just on how the tradition works as a whole and in particular, but, given its checkered history of proximity to the other, how it works alongside or against an opposing tradition. The difference might be analogized to the work that therapists do (treating an individual who is part of a nexus of relationships that he or she brings into the therapeutic encounter), as opposed to the work of couples' counsellors, whose focus is more immediately upon the relationship itself.

Focusing on mixed jurisdictions such as Israel, perhaps most particularly when relationships are frayed, provides an opportunity to look more closely at the processes that create the distinctive legal self, as well as the one that is indiscriminate and promiscuous, or thrown into confusion, or subservient. Israel is often portrayed, however, as an atypical mixed system on the bellum juridicum model fixed on the axes of a domineering Common law being kept at bay by a beleaguered Civil law.

\section{B. Israel's Peculiar Mixité}

In the first event (and one that I want to eventually highlight more starkly), the Ottoman Empire that preceded both the British Mandate and the State of Israel in the region easily meets the second of three features that Vernon Palmer lays out as characteristic of mixité:

The Ottomans, by virtue of granting judicial jurisdiction to foreign powers over their own subjects (allowing for an encroachment on principle of territoriality) and by virtue of granting a broad jurisdiction to religious courts of often transnational reach on both religious and personal status matters would have passed a quantitative threshold "of sufficient proportions as to strike a neutral observer as obvious", which Palmer sets as a striking psychological feature of 
mixté - the second feature. ${ }^{33}$

The historical example of the Ottoman Empire, based on a predominant component of Muslim law mingled (particularly in the $19^{\text {th }}$ century) with Civil law undermines the first feature that Palmer identifies as the core of the "Third Family" of law - namely those systems built upon the dual foundations of Common law and Civil law materials. ${ }^{34}$ In light of a qualified (but, I will argue, still hugely significant) perpetuation of the Ottoman fracturing of religious jurisdiction in the domains of family law and personal status in the State of Israel, the binary nature of the way that mixite is construed in the literature fragments and dissolves in intriguing ways in Israel/Palestine.

Celia Wasserstein Fassberg's contribution to the First Worldwide Congress on Mixed Jurisdictions highlights this anomalous feature of the Israel's mixité - i.e., the reduced salience of the Common law/Civil law opposition as a source of tension. ${ }^{35}$ Although there were early integrity-driven tensions between both the Common law coming out of the British mandate, as well as early tensions about the language with which the Israeli system should be infused, these tensions did not long persist. And, in a trajectory uncommon to other situations of mixité, ${ }^{36}$ Civil law superseded the presence of Common law in Israel with the huge influx of civilian jurists from continental jurisdictions following the Holocaust who left their imprint on both the legal academy and the structure and substance of Israeli law.

Further, as Fassberg points out, mixités characteristic conjunction of legal and linguistic struggles against a dominant Anglo/Common law foil were not present in Israel. Neither English nor continental languages prevailed in Israeli legalese. Hebrew swiftly became the dominant language of law.

And yet, as Fassberg intriguingly lays out, for reasons particular to internal developments within Talmudic law, and for reasons associated with the literary and rhetorical nature of modern Hebrew, a more striking tension between the two predominantly secular traditions of the Western World and Jewish law was not prevalent at the establishment of the new Jewish state. As she notes,

a number of explanations have been offered for the failure of Jewish law to become the model for the new Israeli legal system. It has been said that the thirty years prior to the establishment of the state were among the least productive in the long history of Jewish law, and that the rabbinical establishment had missed the opportunity to develop Jewish law in a number of areas crucial to modern life--contracts, torts,

33 Vernon Valentine Palmer, "A Descriptive and Comparative Overview" in Vernon Valentine Palmer, ed., Mixed Jurisdictions Worldwide: The Third Legal Family(Cambridge: Cambridge University Press, 2001) at 17

$34 \mathrm{Ibid}$. Palmer's third feature is structural, focused on the relegation of Civil law in the private law sphere and the Common law occupation of public law matters, and I will not discuss this third 'feature' of mixité here.

35 Fassberg, supra note 3.

36 Except to the extent that Civil law from Ottoman incorporations persisted in personal status law 
commercial institutions, and the like. ${ }^{37}$

She also points out that the decision was coloured by pragmatic deliberations. "The limited resources of the political establishment," she notes,

had to be marshalled to deal with more immediate problems such as war and massive immigration; the accumulated experience of the world has not produced a very broad range of models for legal systems, and the challenge of inventing an original model is formidable, holding the risk of creating legal vacuums. Perhaps more importantly, there were very few lawyers among the leaders of the socialist Zionist movement. ${ }^{38}$

At least at the inception of the state, which was more predominantly secular and socialist than it is today, Jewish national identity was not principally generated out of the confluence of law and culture or nation. At least at the inception of Israel, neither Common law, nor Civil law, nor religious law were cast as salient antinomies in a bellum juridicum. Integrity-driven judgments were backgrounded to the pragmatic concerns of developing a body of principles, statutes and jurisprudence that could resolve disputes in a manner that gave increasing legitimacy to the inchoate legal system. It mattered less that a legal proposition was civilian or Common law in origin than that it worked - and certainly mattered less than it would to a civilian in other mixed jurisdictions.

Although Wasserstein highlights the reduced significance of the characteristic Common law/Civil law mixité tension in Israel, both she, and Goldstein before her in his contribution to Palmer's edited opus on the world's mixed jurisdictions, downplay the significance of the tensions that have subsequently arisen to central prominence, and persist, between Israel's religious and secular legal traditions. ${ }^{39}$ Just as comparative law texts of the $19^{\text {th }}$ and $20^{\text {th }}$ centuries routinely devoted a hugely preponderant amount of focus to Civil law and Common law and reserved marginal and cursory treatment for the other legal traditions of the world, the mixture of Common law and Civil law figures prominently in discussions of Israeli mixité and the otherwise highly salient tension between state and religion (not just in Israel but increasingly around the world) is relegated and contained within the private branch of law known as family law.

Yet the alter against which a secular Israel/Palestine is composed, increasingly if not originally, is religious law, principally Talmudic and Islamic. In light of the almost inescapable presence of the political tensions around these particular sets of axes in the public imagination (Jewish law and state law, Muslim law and state law, Jewish identity and Arab identity (Christian and Muslim), religious law and secular law), it is surprising that they figure so unremarkably in the literature on Israeli mixité. To the extent that relations have not been domesticated and normalized in the way that they have between Common law and Civil in Israel, the

37 Fassberg, supra note 3 at 174 
residual, sometimes violent, tension along these axes is one of the most striking features of Israel's mixité. ${ }^{40}$ It is also one of the features that almost paradigmatically showcases the bellum juridicum of mixité and provides an opportunity to explore the less pacific dimensions of the dynamic of encounter that (as Palmer also points out) runs through mixité as a recurring theme. The tension also leaves a comparativist poised, I would suggest, to explore the dialogue between merit- and integrity driven judgements in a setting, unlike contemporary Quebec in Canada or Scotland in Britain where a level of (albeit precarious) comfort and complacence about cultural identity has shifted into the background so that grammatical or merit-driven readings of the law can predominate.

As Fassberg points out, Israel's Common law/Civil law mix is sufficiently tangential to the core identity politics of Israel/Palestine that it is characterized by a nonchalance regarding which predominates that is uncommon to the other classically mixed legal jurisdictions. Whatever works, now seems to be the prevailing ethos with regard to Europe's two leading legal traditions. Merit-driven judgments about which solutions from which of these legal traditions provide the most salutary solution have an easier field in Israel/Palestine than they would in jurisdictions such as Scotland or Quebec.

Though perhaps not originally pertinent, the religious law/secular law mix in Israel/Palestine is now far more fraught with the identity politics that Quebec and Scotland have tended to reserve for Civil law. In this regard, Israel/Palestine is embarked upon a dispute that now characterizes many western states; given its geographical location, it also happens to be at the very epicentre of that rising binary opposition. Integrity-driven or integrity-driven judgments can be expected to figure prominently over pragmatic solutions that make the most sense in the circumstances.

The ways in which the balance between merit and identity works out in either of these domains would make interesting papers in and of themselves. However the more salient tension between Israelis and Palestinians (a subset of which tension includes religious legal identity), and the way that this tension gets existentially deployed in the mundane world of food is what preoccupies the rest of this article. This focus hopefully allows for a more robust way of assessing the manifold ways in which merit- and integrity-driven judgments come to the fore or recede in importance and are at the service of a range of agendas.

\section{DISHING IT UP}

This brings me back to my wanderings through the Old City of Jerusalem at the outset of this article. Elements of that prosaic ambling would appear innocuous to a visitor, as indeed they might have to those most habituated to the jumbled streets and alleys of the Old City. It is hard to see which of the elements are fraught, if any, if not all. Those things that an outsider might find salient and

40 One suspects that the weary and anguished fatigue with a state of affairs where things seem to hold little hope of ever being normalized generates a longing to focus on those tensions in law that, like Quebec and Scotland, have moved more comfortably, if somewhat precariously, into the background. 
intriguing, one more habituated might find commonplace; and vice versa.

A classic example of the simultaneous banality and poignancy of events, peripherally related to law, are the activities surrounding Memorial and Independence Day in Israel. Memorial Day is devoted to the memory of those who have given their lives to the State of Israel. Ceremonies are held throughout the country at schools, cemeteries, and memorial sites. Lacrimonious songs dominate the airwaves. A one-minute siren is blown on the eve of Memorial Day and a two-minute siren is blown on the morning of Memorial Day (the end of which also marks the beginning of Independence Day). During the siren, the whole country, it seems, comes to a standstill - people stop working, children stop playing, and traffic comes to a halt as drivers step out of their cars to stand in silence as the siren wails in memory of the fallen. For Jewish Israelis, the day is difficult and emotional; particularly as it lurches from mourning to the joyous celebrations of Independence Day.

This spring, I was told by several people in the Old City that Arab and Armenian café owners at the Jaffa gate had been approached by the police several days prior to the event and told that (though under no legal obligation to do so, the Palestinian Israelis informed me) they had to shut down for Memorial Day with veiled threats made, compounded by circulating rumours, that it they failed to do so, their shops would be vandalized at night.

Jewish Israelis I spoke with, themselves caught up by the intense emotionality of the memorials, said it was normal for the police to visit the shop owners; there was a legal obligation to comply and the police were providing a service by letting them know they were liable for a fine (a banal event).

Whether there is in fact a law obligating Arab shop owners to close on Memorial Day is to a large extent irrelevant to this account in which formal stateimposed memorializing would further compound the dissonance between disparate sense-making of the event. I came across many settings in which the disjuncture between Jewish and Arab responses to Memorial and Independence Day has been for years a source of acute and anguished debate, compounded by the fact that Independence Day for Jewish Israelis is the exact same event as the Naqbah, or catastrophe, for Arab Israelis. The YMCA day-care in Jerusalem, for example, has not only both Arab and Jewish Israeli staff and children in their care, they have an annual conundrum about whether the day-care should bring the Arab children out onto the streets to witness the moment of silence or segregate the two groups of children on that day, or simply decline to recognize the moment institutionally.

Single events that are ritual, routine, and understood by one group are poignant and painful for the other. Things that are part of the backdrop of a routine life for one group are at the forefront of cutting distinctions for another. Which things are the background and which the foreground is not determined, like Wittgenstein's arrow, by the thing itself, "... but only in the application that a living being makes of it." ${ }^{41}$

In the prose amblings from the outset of this article, the Israeli taxing of Kareem's tea business and his refusal to pay, or the style and moment of mingling

41 Supra note 26 at para. 454 
that is Jewish/Arab commerce, are matters that might be depicted, alternatively, as banal or pregnant with larger meaning. It's quite possible to imagine that matters laced with intrigue and urgency at one historical moment might become commonplaces of the past. Though harder to imagine in the contemporary moment, the "separation"/"apartheid" wall and the ubiquitous posters of its construction on Palestinian walls could become as much of the background as the warm, Jerusalem stone facets of the wall that surrounds the Muslim, Armenian, Christian, and Jewish quarters of the Old City.

And so, although the prose amblings might render salient different things at different moments to different observers, I'm going to focus on one element in the amblings that would likely seem innocuous to an outsider as well as (most likely) to the inhabitants of the scenario - that is the food; the rice-stuffed cabbage leaves, the so-called "Israeli salad", the hummous, the falafel....

\section{A. Food's Potent Banality}

Whatever else was salient in the scenarios, the food, as we were taking it in, was pretty much matter-of-factly absorbed as a measure of the quotidian. And yet it too embodies the potential of everything to be infused with the drama of alterity, to carry a weighty cargo of identity, just as the law tends to do in mixed jurisdictions - an ethos conveyed in each banal transaction.

The proclivity of a particular dish to absorb (along with flavour and nutrients) history, ideology, and socio-economic nuance is not a particularly new revelation. It has long been recognized, for example, that cookbooks play a socially didactic role, that social class prearranges our tastes, and that efforts to corral immigrants and the 'lower classes' into a national and political consensus often started, sometimes intrusively, generally insidiously, with their food practices.

Anthropologists and cultural historians have elaborated upon the politics of trading, purchasing, preparing, and consuming food. ${ }^{42}$ And they have also expanded upon the intra-societal significance of food practices to link them to the ways in which food is used (as is law) to reproduce class, gender, cultural, and national identity. As Bourdieu has elaborated in his seminal work on the topic of taste, class structures, once in place, replicate themselves through a myriad of subtle markers of distinction. Not only do class differences profoundly divide access to the resource of food, both in quantity and quality, these differences are further entrenched by a series of signifying stratifications that highlight class distinction. So, for example, fish might be construed as an effeminate food for working class men $^{43}$ while fresh vegetables and lean meat mark the diets of the

42 A considerable body of anthropological literature has been devoted to the topic of food and its relation to cultural politics. See, for example, Andrew Dalby, Dangerous Tastes: The Story of Spices (Berkley and Los Angeles, University of California Press, 2000); Sidney W. Mintz, Sweetness and Power: The Place of Sugar in Modern History (New York: Penguin, 1985); Jeffrey M. Pilcher, Que Vivan Los Tamales: Food and the Making of Mexican Identity (Albuquerque: University of New Mexico Press, 1998); Hasia R. Diner, Hungering for America: Italian, Irish, and Jewish Foodways in the Age of Migration (Cambridge: Harvard University Press, 2001)

43 Pierre Bourdieu, Distinction: A Social Critique of the Judgment of Taste (Boston: Harvard University Press, 2007) 
elite. So, for example, in Canada, a current television ad has, ostensibly, a working Joe reinforce to his son (while his cunning wife is in the background at the stove preparing and serving the meal) associations between the consumption of "healthy" food and the effete and pathetic neighbours - all the while unwittingly consuming the whole wheat pasta that his wife has surreptitiously slipped under his spaghetti sauce. These are the kinds of fine-grained associations of food preferences with class alluded to by Bourdieu that are subtly inculcated, generation to generation.

Hasia Diner underlines this capacity for food to facilitate social reproduction when she notes that "...both systems of food and sexuality strengthen bonds between group members and create barriers to interactions with outsiders. Put bluntly, the person with whom one cannot eat (and whose food cannot be consumed) is often the same person with whom sexual relations must be avoided. Food, like sex, intensifies group identity." ${ }^{4} 4$

Further links between food and sexuality have been connected around the axis of gender, suggesting that the significance of food, like law, resonates on many registers of social life, within all societies. Diner remarks upon how "gender, understood as any culture's knowledge of, and beliefs about, sexual difference would come into play around food." Not only are different roles and rituals assigned to different domains of interaction with food gathering, preparation, and consumption, extensive fields of social life are organized according to these foodrelated assignations of role and ritual. Even subtle disruptions and conformity to those assignations carry import for the larger culture as a whole. It can matter as much to self-conceptions of the western world that women do not only serve the men the food they have cooked, do not only eat after the men have finished, and do not deny themselves particular food items, as it matters in other societies that they do. For an individual woman within either setting to disrupt or conform to expected norms says as much about the social arrangement as a whole as it says about her individual actions.

Where Bourdieu notes, in his seminal work on the topic of taste, that "taste classifies, and it classifies the classifier", the same kinds of signifying stratifications that he highlights along the lines of class can be observed between cultural and national groups. Indeed the elaborate and nuanced taxonomies of intrasocial distinctions are often the same ones that feed into national and territorial jurisdictions. What and how a group eats, who prepares food and how, and with whom food is consumed have marked the 'natural' borders between the peoples whose self-determination is linked to statehood, again in a manner that has some analogies to the ways in which a style of adjectival and substantive law has distinguished common from Civil law jurisdictions, and the visceral way that an imposed national border can feel like a violation of the natural order, an affront to community tastes and values.

Food, very much like law, is both culturally constructed ("what [is] tasty to one group invoked disgust and loathing in another" ${ }^{35}$ ) and laced with ideology.

44 Diner, supra note 42 at 4 .

45 Ibid. at 3 
The analogous questions to Glenn's merit-driven judgments, or to the 'pragmatists" amongst the mixité scholars (What tastes good? What provides the most nutrients and energy? What best makes up a balanced diet?) are equally difficult to answer outside of the culinary context in which they might be asked. Indeed, these questions directed to the 'essence' of food, themselves reveal (as do, one suspects, questions about merit and pragmatism) a particular set of culinary values: the triumph of bland scientism and a universalizing of the National Food Guide.

If Glenn's merit-driven judgments have an analogue in the world of food, so too does the openness prized by Örücü and Kasirer as value for the next generation of mixité. Writing against a tendency of Scottish judges and jurists to cleave to a strong emotional belief in the existence of an organic connection between the practical principles of private law and the character of the Scottish people, Örücü cautiously wonders whether such a linkage between law and national identity would be desirable. "Surely," she remarks, "under new political and constitutional conditions, devolution will open the system up to a broader range of influences. To take this opportunity is vital." 46 The sentiment has an echo in a distinct strain of cookbooks that celebrate innovation over tradition.

Kasirer is bolder in affiliating inventiveness with métissage, not just the making of new and unexpected combinations out of familiar ingredients, but the creation of new combos out of the mixing of unfamiliar ingredients. The overlaps with fusion cuisine - which combines elements of various culinary traditions whilst not fitting specifically into any - are evident. Just as "the mixed legal system is rightly connected with an unimpeachable ethic of tolerance as well as the promotion of scholarly interest in multiple cultural identities and pluralism", fusion cuisine emerged in the 1970 s out of a self-conscious attempt to reconcile the realities of world travel, mass migrations, and the intermingling of distinct ethnic groups in dispersed urban settings by an adventurous blending flavours and ideas from different cultures. In both cases the sensibility is self-conscious, the emboldening call to adventure and inventiveness prescriptive.

It is the further normative evaluation of this cosmopolitan approach to cuisine as a whole, and in comparison with other cuisines - the endorsement of distinct sensibility behind it - that I want to ponder at this juncture, quite possibly because it is the sensibility that is so close to my own.

It is clear that Kasirer, of all of the writers on mixité, is committed to wrestling the subject out of its taxonomic preoccupation with "the reconciliation of difference, in an imagined whole, both coherent and static, in which the experience of encounter is absent or forgotten or past or digested or pre-determined." ${ }^{37}$ I want to push that understanding one step further in questioning the valorization of the thrilling and somewhat dangerous and precarious state of openness that is associated with it. This I want to do to get back to the "sometimes this and sometimes that" of Wittgenstein's approach; the awareness that things "sometimes leave room for doubt and sometimes not", ${ }^{48}$ including doubts about

46 Örücü, "Second Renaissance” supra note 14 at 101

47 Kasirer, supra note 4 at 500

48 Wittgenstein, supra note 26. 
the virtues of métissage and fusion, leaving us hopefully more poised to follow Wittgenstein's admonition to look and see.

\section{B. Israeli/Palestinian Food - The Dynamics of Mixité}

In a review article of A Full Belly: Rethinking Food in Society in Israel, professor of Hebrew literature at Ben-Gurion University, Yahil Zaban notes that

Israeli cuisine is portrayed in cooking columns and television programs as an end-of-days vision-come-true: Gefilte fish shall dwell with hilbeh (Yemenite fenugreek dip), in equality and brotherhood. On the surface, it is a cuisine that puts the theory of national-culinary fusion into practice, taking the finest spices and cooking styles of Israel's various ethnic communities, and whipping up a marvellous dish that unites East and West, Jew and Arab, rich and poor. ${ }^{49}$

A Full Belly, she notes, offers a more sober view of the status of food in Israeli society. The review, mirroring the book, offers a range of sociological critiques of food, including analysis of how ethnic dishes in Israeli society reflect the standing of the communities associated with them, of how Israeli society attempted to carve out a normative identity for itself through food socialization, and of the interactions between the domestic and national spheres reflected in national food guides.

There is a further feature of Israeli food as a sociological phenomenon that mirrors, to some extent, the kinds of antinomic tensions between religious and secular law that seem oddly backgrounded in accounts of mixite, with the most upsetting encounters left out. This is the way that food, as an idea or cultural marker, feeds flashpoint tensions between opposing cultural and national groups in Israel/Palestine, symbolized by the way that, as Jodi Kantor puts it, the humble chick pea contains a history ripe with Middle Eastern politics. ${ }^{50}$ Just as the law can be innocuous and commonplace or can be a substitute for a panoply of secondary tensions, food can be marshalled for war. And one of the items in my prose amblings that ordinarily would go relatively unnoticed (namely food) can rapidly lose its quotient of nutritional merit (good taste, nutritional balance) and take on ideological proportions.

Kantor's article focuses on how the ways that historically Palestinian foods such as tahina, hummus, falafel, and pita bread are now markers of Israeliness, an appropriation that sets Palestinian teeth on edge. Falafel, in particular, has become a locus of Israeli-Palestinian politics, not isolated to the Middle East. Canadians will recollect that one dimension of the tensions between Jews and Palestinians at Concordia University in 2002 was focused on food: two days after the campus was shaken by violent protests over the Middle East, a Palestinian student at orientation week accused a Jewish group of cultural theft for stealing

49 Yahil Zaban "And Gefilte Fish Shall Dwell with the Hilbeh”, Ha'aretz, (6 January 2006).

50 Jodi Kantor "A History of the Mideast in the Humble Chickpea" online: e-cookbooks <http:// www.e-cookbooks.net/articles/chickpea.htm> (accessed February 5, 2006). 
falafel, shouting "Hillel is stealing Arab food" into the crowd. ${ }^{51}$

Writers on the identity politics of Israeli/Palestinian food have pointed to the subtle ways in which appropriation manifests itself through history in a manner consonant with Edward Said's analysis of orientalism. "Politically, the Zionists ignored the Arabs, but culturally, they romanticized and tried to imitate them," writes Yael Zerubavel, a scholar of Israeli culture at Rutgers. "This imitation didn't seem like theft, but localization, a process of putting roots in soil." "52 These kinds of Jewish/Palestinian arguments about falafel," Kantor points out, "reflect the wider conflict, touching on debates over territory and history." This metonymic capacity of food to identify more complex entities is echoed by Ammiel Alcalay, Jewish professor of Middle Eastern culture at Queens College, who argues that the 'appropriation' of falafel, or Jaffa oranges, or the spice mixture zaatar "is linked to very concrete things like land and sustenance." ${ }^{3}$ The polysemy of food it appears, like law, renders it as susceptible to an unruly range of meanings as it is to more matter-of-fact consumption.

And yet, though sufficiently salient that in another moment it had the hot lights of national media glare surrounding it at a student orientation table on the campus of Concordia, the falafel being dished up, stuffed with French Fries (apparently an Israeli innovation) along the roads and alleys of the Old City last year were about as pedestrian and humble as the chickpea has ever seemed. The hummus being sold a couple of doors down from Ghassan's shop stands out more for the Jewish tour guide's claim that it's the best in Israel than for being a locus of overheated anxieties about land and sustenance. The hundreds and hundreds of falafels and pita breads lathered in hummus consumed every day in the Old City, like the law and like commerce, go unnoticed as they fulfill their more prosaic vocation to sustain. That's not to say that either could not, in an instant, be transformed (in a way that is for now more distantly familiar in Quebec and Scotland) into objects bearing the full weight of Middle Eastern politics. Like Wittgenstein's arrow, they sometimes leave room for doubt and sometimes not, fundamentally acquiring their meaning in the ever-changing applications that living beings make of them.

The metaphor of food for studies of mixité then, echoes Lasser's point that sometimes grammatical readings of texts are culturally fore-grounded, sometimes hermeneutical; but indispensably, taut configurations containing both are foundational in mutually implicated ways in the practices of law. And therefore both, like the humble chickpea, are susceptible to precariousness and prone to unsettle our most settled classifications for the way the law, mixed or unmixed, regularly works.

Legal mixité then, pervasive a phenomenon as it is, will have elements of permixtum - of things being mingled in the most pedestrian and routine of ways - as well as elements of promiscum, with things interacting indiscriminately,

51 I.Peritz and T.Thanh Ha "Concordia, A Campus in Conflict: Tensions between Arab, Jewish students poison atmosphere at Montreal university” Globe and Mail (Canada) (14 September 2002)

52 Cited in Kantor, supra note 50 at XXX.

53 Ibid. 
sometimes promiscuously, nonchalant about throwing things into confusion. And it will have elements of bellum, as the mundane and the commonplace are highlighted against the stakes and perils of the indiscriminate. To ask that the values of good taste prevail in this confusion, as a call to either merit or a general state of openness implies, is to miss the sometimes this and sometimes that out of which distinctions of good or bad bubble up - along with the passion and thoughtfulness that such qualifications arouse.

Food, then, if it is going to work as a metaphor for mixité, would best be fully dished up as the sometimes matter-of-fact, sometimes fraught, locus of encounter that characterizes the rest of human activity. 